\title{
Analysis of quality indexes of the provided health services in public and private services of Angola
}

\author{
Maria Teresa Conceição Vicente ${ }^{1,2}$, Rodrigo Daminello Raimundo ${ }^{2,3^{*}}$, Ligia Ajaime Azzalis ${ }^{4}$, \\ Virginia Berlanga Campos Junqueira ${ }^{4}$, Fernando Luiz Affonso Fonseca ${ }^{2,4}$
}

DOI: http://dx.doi.org/10.7322/jhgd.119280

\begin{abstract}
Introduction: Quality indices are being increasingly used by leaders, managers and health professionals as operational tools to improve processes and reduce costs. Noting that there is a greater tendency of private hospitals operating in the regulatory model for market mechanisms, it is expected that the quality indicators that serve as a reference for monitoring the health management are more critical in public hospitals.

Objective: Evaluate the quality of health services provided in public and private service in Angola.

Methods: We analyzed 142 patients of a public and a private institutions in Angola in a structured interview on health indicators. The indices were collected according to the process structure components and results.

Results: There are 51,453 calls in the public institution, remaining hospitalized a day, an average of 184 patients, with an annual rate of bed occupancy of $90.84 \% .50 \%$ of respondents praised the services and $22 \%$ complained about the quality of services. He was appointed as the main grounds for complaint the slow service (17\%). The private institution received 2,222 patients, with an average of 570 patients. The mean hospital stay was 4.5 days. The average monthly rate of bed occupancy was $59.9 \%$. In assessing the degree of satisfaction of care, regular or bad satisfaction obtained a rate of $60 \%$ in the private institution.
\end{abstract}

Conclusion: There was no favorable results for quality in health management both in public service and in private.

Key words: health management, quality of health care, health care evaluation.

\section{INTRODUCTION}

The national health system in Angola passed by a historical evolution characterized by two distinct periods: the colonial and post-independence periods ${ }^{1}$. The colonial period was characterized by a health system accessible to a privileged minority, targeted at solving their health problems and affecting the economic productivity of the colonia ${ }^{2}$.

From the introduction of political, economic and administrative reforms made in Angola, the Act No. 21B/92, of 28 August stands out among them, the law Bases of the National Health System that says that the State has no longer exclusivity in health care, with the legalization of the private sector. Was also introduced the notion of co-participation of citizens in health costs, maintaining the free and universal system ${ }^{1,2}$.

The system of health care delivery stratifies into three hierarchical levels of provision of services, based on the Primary Health Care (PHC) strategy ${ }^{1,3}$. The primarylevel - Primary Health Care (PHC) - represented by stations, health centers, municipal hospitals, nursing stations and doctors' offices, is the initial point of contact with the health system. The secondary or intermediate level, represented by general hospitals, is the reference level for first-level units. The tertiary level, represented by referral

\footnotetext{
1 Ministério da Saúde de Angola.

2 Faculdade de Medicina do ABC, Santo André, SP, Brasil.

3 Faculdade de Saúde Pública da USP, São Paulo, SP, Brasil.

4 Universidade Federal de São Paulo, Diadema, SP, Brasil.

Corresponding author: Rodrigo Daminello Raimundo - Email: rodrigodaminelloraimundo@.usp.br
}

Suggested citation: Vicente MTC, Raimundo RD, Azzalis LA, Junqueira VBC, Fonseca FLA. Analysis of quality indexes of the provided health services in public and private services of Angola. J Hum Growth Dev. 26(2): 228-233. Doi: http://dx.doi.org/10.7322/jhgd.119280. Manuscript submitted: Mai 18 2016, accepted for publication Jun 142016. 
hospitals mono or multipurpose, differentiated and specialized, is the reference level for secondary-level health units $^{1-3}$.

Despite this clear hierarchy, the reference system has not been operational for several factors, mainly because of the disruption of the health care system and reducing health coverage arising from the long conflict that Angola lived ${ }^{1,2}$.

It is estimated that only about 30 to $40 \%$ of the Angolan population have access to health services. The public and private sectors make the provision of health care. The public sector includes the National Health System (NHS), the health services of the Angolan armed forces and the health services of the Ministry of the Interior this sector remains as the main provider of health services at the national level, sharing with other service providers, the same difficulties of health care delivery without the desired quality in most cases, despite the progress lately recorded ${ }^{3-5}$.

The co-participation health costs in the public sector was recognized as a barrier to access to health care and to fairness. Therefore, the lucrative private sector is confined to major urban centers of the country and is sluggish at the tertiary level, with prices that limit the accessibility of the population. Similar to what happens in the public sector, the quality of private services are still lagging behind. Mostly, the functionalism of the private sector is the same as working in the public sector, with obvious damage to both. However, it is not known whether there are differences between the sectors with regard to the contents of management ${ }^{2,5-7}$.

In the World Health Organization's perspective, the quality of health care is based on a set of elements that include a high degree of professional competence, efficiency in the use of resources, minimal risk, a high degree of patient satisfaction and a favorable effect on health ${ }^{8,9}$.

Quality management concepts were developed in the industrial context, initially from American thinkers. According to Norman ${ }^{10}$, the idea of measuring the quality of health services began to be developed in the 1960 decade, by Donabedian ${ }^{11,12}$, at the University of Michigan (USA). Donabedian ${ }^{12}$ launched an evaluation methodology and qualification with regard to structure, process and results in health services. "The quality criterion is nothing more than value judgment”, said this author. The definition of quality in health "reflects the current values and goals of a particular health system and society as a whole of which it is part"12.

The indexes are usually defined as numbers that measure the relative variation of a quantity between two different situations, in time and space, or compare situations observed with those expected, being one of those situations taken as reference or basis for calculating ${ }^{13}$. Are basic tools for managing organizational system, that is, measures used to help describe the current status of the given phenomenon or problem, making comparisons, check changes or trends and assess the implementation of the planned actions for a period of time, in terms of quality and quantity of health actions performed. Vaz ${ }^{14}$ says that the indicators can be simple or compound.

Noting that there is a greater tendency of private hospitals operate in market regulation model, quality indexes, which serve as reference for the monitoring and evaluation of health management, are more critical in public institutions, with greater dependence on State resources than in private. Having as its mission producing best quality care possible at the lowest cost, the health system has a doubt about the quality of care. Therefore, the objective of this study is to evaluate the quality on health management of Angola, comparing a public and a private.

\section{METHODS}

This is an observational, descriptive and transversal study of quantitative and qualitative approach held in public and private institutions in a municipality of the city of Luanda. The public institution studied was the motherhood Lucrécia Paim - specialized in women and neonate through preventive and curative services - located in the municipality of Ingombotas (Luanda, Angola).The private institution studied was the Sunflower clinic, located in the municipality of Maianga (Luanda, Angola).

This research was approved under the number 213/2013 Research Ethics Committee (REC) of the Faculdade de Medicina do ABC. After the individuals signed an informed consent (TFCC), a structured interview with open and closed questions on health indicators was used.

The contents were collected from face-to-face interviews with patients that happened in the period of $02 / 23 / 2012$ to $02 / 11 / 2013$, obtaining permission for getting the data according to the components of structure (human resources, occupied beds and the ones available); of process (time of unoccupied beds, number of hospitalacquired infections, patients treated in each unit per day, month and year and stay of hospitalization for specialties) and outcomes (patients who performed clinical/surgical treatment, total of hospital discharge in the institution and attendance satisfaction).

The questionnaire contained 28 opened questions with the following doubts: "are you satisfied with the service at the hospital?"; "How many patients are serviced on each drive per day?”; "And every day of the month?”; “And in the year 2013?”; “How many days patients remain hospitalized?”; "How many beds are occupied by day each month?"; "How many beds are in each hospital unit?”; "How many time the beds remain unoccupied by day?”; "How many beds will remain available to patients in a day?"; "How many patients have high in each hospital a day?"; "What is the total number of discharges in the institution?"; "How many deaths occur per day?”; "How many hospital discharges occurred per

\footnotetext{
* In the mid-20 $0^{\text {th }}$ century, the values embedded in the Hippocratic Oath were endorsed and reaffirmed in the Declaration of Geneva adopted by the UN $2^{\text {nd }}$ General Assembly in 1948 and amended several times, most recently in 2006. Later, the Declaration of Helsinki adopted in 1964 and revised several times, most recently in 2013, set the standards for medical research ethics. Both documents, while not legally binding instruments under international law, contain ethical principles guiding healthcare professionals worldwide.
} 
day?"; "How many patients had clinical/surgical treatment performed by day?”; "Medical supervision was conducted?"; "How many medical shifts were carried out per week?"; "How many medical visits were made a week per patient?"; "How many cesarean sections were performed per day?”; "How many cesarean sections were performed per month?"; "What is the total number of births?”; "How many employees the hospital unit has?”; "How many employees were let go a day?”; "How many employees were hired by day?”; "How many employees lacked a day?"; "How many hours employees lacked a day?”; "How many accidents at work occurred per day of each month of 2013?”; “How many hours of training employees had per day?”; "How many cases of hospital infection in bloodstream occur per day?” and "What is the hospital mortality rate?".

Data were collected and tabulated in a spreadsheet in Excel software. They were analyzed using descriptive statistics, reported in absolute frequency, relative frequency and average.

\section{RESULTS}

The main features of public and private service in Angola are presented in table 1. The public institution studied has an average of 141 patients treated daily, 4,287 monthly and 51,453 annually. By day, 184 patients on average remain hospitalized, 5,617 per month and 67,479 per year with an annual occupancy rate of beds $90.84 \%$. An average of 147 patients have discharge daily, and 4.476 monthly. The replacement interval of unoccupied beds is 0.13 days. The total of 41 surgeries are performed daily, 256 monthly and 15.076 yearly. In 2013, 21 caesarian sections were performed per day, 642 per month and 7.713 per year and there were 469 cases of nosocomial infection in bloodstream. In this hospital, the supervision is performed daily by the Clinical Director. An medical shift is made in each 4 days. Each patient receives a medical visit per day.

The information was collected in the period from $2 / 23 / 2012$ to $2 / 11 / 2013$, and provided by the Information Sector. The total 142 patients were interviewed. Half of those surveyed praised the public service. The total of $28 \%$ did not make comments, and 22\% complained about the services quality. Key reasons of complaints are: timeconsuming attendance (17\%); absence of more humane care in the treatment; delay in meeting the urgent bank (8\%); Lack of humanism in emergency bank; small room (8\%); Information Sector with no chairs to accommodate the escorts; delay in providing information to family members; lack of cleaning in the bathrooms of the patients (8\%); lack of restaurants (3\%); lack of ramp and slippery waiting room (3\%).

The particular institution has a hospital stay with 22 operational beds, intended for the reception of patients of gynecology and obstetrics aspects. Pregnant women with pregnancy-related pathologies are admitted in the individual or collective rooms or in isolation rooms (a bed with air renewal system for HEPA filters). For those who have recently given birth the same concept is followed. At hospitalization are interned in different rooms who have recently given birth, pregnant women and patients with gynecological problems. When there is need for hospitalization in intensive care, the woman who has recently given birth or patient with gynecologic problems is hospitalized in intensive care for adults (Table 1).

The specialties of Gynecology and obstetrics received in the year under review 2.222 patients, with a monthly average of 570 patients. The total of 1.623 patients where hospitalized, with a monthly average of 135 patients. The average time of hospitalization is 4.5 days. The average monthly rate of occupancy of beds is $59.9 \%$. In the same specialties, the replacement range is 3 days (Table 1 ).

Table 1: Public and private services characterization in Angola

\begin{tabular}{|c|c|c|}
\hline & Public Institution & Private Institution \\
\hline \multicolumn{3}{|l|}{ Attendance numbers } \\
\hline Monthly average & 4.287 patients/month & 570 patients/month \\
\hline Annual average & 51.453 patients/year & 6900 patients/year \\
\hline \multirow[t]{2}{*}{ Specialties } & Gynecology and Obstetrics & Gynecology and Obstetrics \\
\hline & Neonatology & Neonatology \\
\hline \multicolumn{3}{|l|}{ Hospital stay } \\
\hline Monthly average & 5617 patients/month & 135 patients/month \\
\hline Annual average & 67479 patients/year & 1623 patients/year \\
\hline Annual occupation tax & $90.84 \%$ & $59.9 \%$ \\
\hline Changeover time & 0.13 days & 3 days \\
\hline \multicolumn{3}{|l|}{ Surgeries number } \\
\hline Monthly average & 256 surgeries/month & 190 surgeries/month \\
\hline Annual average & 15076 surgeries/year & 2274 surgeries/year \\
\hline \multicolumn{3}{|l|}{ Hospital infecctions } \\
\hline Anual tax & $0.9 \%$ & $1.9 \%$ \\
\hline Patients average (year) & 469 & 131 \\
\hline
\end{tabular}


This private institution works with 88 doctors per day, 39 health technicians and 20 administrative and technical support workers. The index of hour/man/training established contractually is 4 hours a week, which are part of the workdays of all workers.

In the hospital that was carried out during the period under study, 1.614 surgical interventions in the main block were made, with a monthly average of 135 acts, and 660 surgeries. The procedures performed by the gynecology were $4.5 \%$, in the main surgical block.

There has been a gross annual rate of $1.90 \%$ hospital infections, with a monthly average of $0.15 \%$. Were 203 deaths in the hospitalization of gynecology and obstetrics occurred in January 2013, with a monthly average of 17 deaths (Table 2).

The praise, expressing satisfaction or thanks for services rendered were only $15 \%$. The degree of satisfaction "excellent" offers a reduced rate of only $7 \%$. The degrees of "very good" and "good" had 33\% of responses. There is prevalence of responses indicating the degree of satisfaction "regular" and "bad" of $60 \%$. Complaints or reports of dissatisfaction in relation to actions and health services, recorded mainly through face-to-face care, were $26 \%$. All requests or application for access to health actions and services accounted for $14 \%$. Suggestions for improvement accounted for 32\% (Table 2).

Table 2: Evaluation of the quality of public and private service in Angola

\begin{tabular}{|c|c|c|}
\hline & Public Institution & Private Institution \\
\hline Service quality & $\begin{array}{l}50 \% \text { Excellent } \\
00 \% \text { Good and Very Good } \\
22 \% \text { Regular and Bad } \\
28 \% \text { not commented }\end{array}$ & $\begin{array}{l}\text { 07\% Excellent } \\
33 \% \text { Good and Very Good } \\
60 \% \text { Regular and Bad } \\
\text { 00\% not commented }\end{array}$ \\
\hline Complaint reasons & $\begin{array}{l}\text { Time consuming attendance } \\
\text { Not humanized attendance } \\
\text { Small attendance room } \\
\text { Delay on giving information to familiars } \\
\text { Lack of cleaning in the bathrooms }\end{array}$ & $\begin{array}{l}\text { Time consuming attendance } \\
\text { Not humanized attendance } \\
\text { Delay on giving information to } \\
\text { familiars }\end{array}$ \\
\hline
\end{tabular}

\section{DISCUSSION}

This research aimed to evaluate the quality levels in the management of health of Angola, comparing public and private hospitals. It began with a search context, where a framework of the health sector in the country was made. To support the research, was offered a literature on hospital management, its origin, as well the introduction of indexes of quality in healthcare management.

From the perspective of Borba and Grandson ${ }^{15}$, are the expansion of healthcare systems and the increasing complexity of care that have strengthened the importance of a more effective management of the resources sector and the quality of care. In addition, the growth in demand for health services, the increased costs and restrictions, in addition to the constant changes in clinical practice have expanded the interests of various Nations for the monitoring of health services. It is admitted that have still been adapted to the health area, different techniques and tools, often used in the industrial sector ${ }^{16-18}$.

Our results show $50 \%$ positive rating on public institution of Angola. Although half of respondents praising the institution, believe that this fact can be explained due to the low purchasing power ${ }^{3,4}$ of the population of Angola, being difficult to people who can only use the public service compare with some better quality service.

Studies ${ }^{19-23}$ show that one can use the corporate strategic analysis to improve health planning. Berwick ${ }^{17}$, giving concrete examples of the use of traditional tools of quality, supports this view when he says that "it is possible to adapt the concepts of quality used in the industry for the health sector with some ease”. The results proved being favorable for private institution and not to the public institution. Both of them have pointed out many situations where performance is below the requirements of total quality, lack of effort in quality management.

In general, the quality evaluation is performed looking measure structural conditions of services, since the physical parameters, license, and/or equipment performance, D’Innocenzo, Adami and Cunha ${ }^{19}$ defended. Other ways to accomplish the evaluation are process indicators, tasks or sensitivity function specification of medical care and appropriate therapeutic indication and application. According to Donabedian ${ }^{24}$, the notion of structure, process and result can be adapted to hospital attendance.

The "structure" component corresponds to relatively stable and required the assistance process, covering the physical area, human resources (number, type, distribution and qualification), material and financial resources, information systems and regulatory technical-administrative instruments, political support and organizational conditions. The "process" component corresponds to the provision of assistance according to technical and scientific standards established and accepted in the scientific community about a particular subject and the use of resources in its quantitative and qualitative aspects. Includes the recognition of problems, diagnostic methods, diagnosis and care. The "results" component corresponds to the consequences of activities in health services, or by the professional in terms of changes in the health conditions of the patients, considering also the changes related to knowledge and behaviors, as well as user satisfaction and the worker attached to the receipt and provision of care, respectively ${ }^{24-26}$.

Although there are a number of difficulties to assess quality in the health area, there is a unanimity 
among managers that it is necessary to choose the evaluation systems and adequate institutional performance indicators to support the administration of services and provide decision making at the lowest degree of uncertainty ${ }^{24,25,27}$.

An indicator can be defined as a sensor that helps to verify that the proposed objectives were achieved or not. The creation of indicators is extremely important for the evaluation of the quality, as it provides a measure and allows the monitoring and the identification of opportunities for improvement of services and positive changes in relation to the scope of quality at a reasonable $\operatorname{cost}^{24,25,27}$.
However, the design of this study does not allow a generalization of the evidence found. Even with half of the respondents satisfied, the public institution showed better technical efficiency that the private institution.

Finally, we conclude that there was no favorable results for the quality of provided health services in both the public and private services. The organization of the health system in Angola is relatively recent, the evaluation of the same in public and private is something not much explored, and realizes the need to promote management tools to ensure improvements in global health services.

\section{REFERENCES}

1. Diário da República de Angola. Decreto Lei n 21-B/92 de 28 de Agosto. [cited 2016 Mar 03] Available from: http://www.audiconta-angola.com/?page_id=1017.

2. Diário da República de Angola, Decreto Lei n⿳0 262/10, de 24 de Novembro. cited 2016 Mar 03] Available from: http://www.audiconta-angola.com/?page_id=1017.

3. Comitê Regional Africano. Organização Mundial da Saúde (OMS). Revitalização dos sistemas de saúde no contexto dos cuidados primários de saúde na região africana, 2006. cited 2016 Mar 03] Available from: http://afrolib.afro.who.int/RC/RC\%2056/Doc_Por/AFR\%20RC56\%2012.pdf.

4. Ministério da Administração do Território/Programa das Nações Unidas para o Desenvolvimento. Desconcentração e descentralização em Angola. v. II. Luanda: Ponto UM. Indústria Gráfica; 2007.

5. Fundo de População das Nações Unidas. Características gerais da população de Angola, 2006. cited 2016 Mar 03] Available from: http://www.angola.unfpa.org/popang.htm.

6. Instituto Português de Apoio ao Desenvolvimento. Angola: cited 2016 Mar 03] Available from: http://www. ipad.mne.gov.pt/index.php?option=com_content\&task=view\&id=29\&ltemid=60

7. Menezes S. Mamma Angola: sociedade e economia de um país nascente. São Paulo: Edusp; 2000.

8. Organização Mundial da Saúde. Estratégia da OMS de cooperação com os países: Angola, 2002-2005. cited 2016 Mar 03] Available from: http://www.who.int/countryfocus/cooperation_strategy/countries/ angola_2002_2005_portuguese.pdf.

9. rganização Mundial da Saúde (OMS). Avaliação dos programas de saúde: normas fundamentais para sua aplicação no processo de gestação para o desenvolvimento nacional na saúde. Genebra; 1981.

10. Norman AH. Qualidade em saúde. Rev Bras Med Família Comunidade. 2012;7(23):67-8. DOI: http:// dx.doi.org/10.5712/rbmfc7(23)655

11. Donabedian A. Basic Approaches to assessment: Structure, Process, and Outcome. In: AvedisDonabedian, Explorations in quality assessment and monitoring vol. III. Ann Arbor MI: Health Administration Press; 1980; p.77-125.

12. Donabeian A. Evaluating the quality of medical care. Milbank Mem Fund Q. 1966;44(3):166-206. DOI: http://dx.doi.org/10.2307/3348969

13. Hartz ZMA, Champagne F, Leal MC, Contandriopoulos AP. Mortalidade infantil "evitável" em duas cidades no nordeste do Brasil: indicador de qualidade do sistema local de saúde. Rev Saúde Pública. 1996;30(4): 310-8. DOI: http://dx.doi.org/10.1590/S0034-89101996000400004

14. Vaz JC. Avaliando a Gestão. cited 2016 Mar 03] Available from: http://polis.org.br/publicacoes/avaliandoa-gestao/.

15. Borba GS, Kliemann Neto FJ. Gestão hospitalar: identificação das práticas de aprendizagem existentes em hospitais. Saúde Soc. 2008;17(1):44-60. DOI: http://dx.doi.org/10.1590/S0104-12902008000100005

16. Adami NP, Maranhão AMSA. Qualidade dos serviços de saúde: conceitos e métodos avaliativos. Acta Paul Enferm. 1995;8(4):47-55.

17. Berwick DM. Melhorando a qualidade dos serviços médicos, hospitalares e da saúde. São Paulo (SP): Makron Books; 1995.

18. Bosi MLM, Chimura KY. Avaliação qualitativa de programas de saúde: contribuições para propostas metodológicas centradas na integralidade e na humanização. In: Bosi MLM, Mercado FJ. Avaliação qualitativa de programas de saúde: enfoques emergentes. Petrópolis: Vozes; 2006. p. 87-117.

19. D'Innocenzo M, Adami NP, Cunha ICKO. O movimento pela qualidade nos serviços de saúde e enfermagem. Rev Bras Enferm. 2006;59(1):84-8. DOI: http://dx.doi.org/10.1590/S0034-71672006000100016

20. Porter ME. Competitive strategy: techniques for analysing industries and competitors. New York: Free Press; 1980.

21. Porter ME. Competitive advantage: creating and sustaining competitive performance. New York: Free Press; 1985. 
22. Porter ME. The competitive advantage of nations. Harvard Business Review. 1990; p.73-93.

23. Mintzberg H. Generic strategies: toward acomprehensive framework. In: Shrivastava P. Advances in strategic management. V.5. Greenwich: Jay Press; 1988; p.1-67.

24. Donabedian A. Basic approaches to assessment: structure, process and outcome. In: Donabedian A. Explorations in Quality Assessment and Monitoring: the definition of quality and approaches to its assessment. Michingan: Health Administration Press; 1980; p. 77-125.

25. Bittar OJNV. Indicadores de qualidade e quantidade em saúde. Rev Adm Saúde. 2001; 3(12): 21-8.

26. Bittar OJNV. Indicadores de qualidade e quantidade em saúde. Parte II. Rev Adm Saúde 2004; 6(22): 15-8.

27. Riveira FJU, Artemann E. Planejamento e gestão em saúde: histórico e tendências com base numa visão comunicativa. Ciênc Saúde Coletiva. 2010;15(5):2265-74. DOI: http://dx.doi.org/10.1590/S141381232010000500002

This article is distributed under the terms of the Creative Commons Attribution 4.0 International License (http://creativecommons.org/licenses/by/4.0/), which permits unrestricted use, distribution, and reproduction in any medium, provided you give appropriate credit to the original author(s) and the source, provide a link to the Creative Commons license, and indicate if changes were made. The Creative Commons Public Domain Dedication waiver (http://creativecommons.org/publicdomain/zero/1.0/) applies to the data made available in this article, unless otherwise stated.

\section{Resumo}

Introdução: índices de qualidade estão sendo cada vez mais utilizado pelos líderes, gestores e profissionais de saúde como ferramentas operacionais para melhorar os processos e reduzir custos. Observando que há uma maior tendência dos hospitais privados que operam no modelo regulatório para os mecanismos de mercado, espera-se que os indicadores de qualidade que servem de referência para o acompanhamento da gestão da saúde sejam mais críticos em hospitais públicos.

Objetivo: Avaliar a qualidade dos serviços de saúde prestados no serviço público e privado em Angola.

Método: Foram analisados 142 pacientes de um hospital público e uma instituiçãao privada em Angola, em uma entrevista estruturada sobre os indicadores de saúde. Os índices foram obtidos de acordo com os componentes da estrutura de processo e resultados.

Resultados: Não são 51,453 chamadas na instituição pública, permanecendo internado por dia, uma média de 184 pacientes, com uma taxa anual de ocupação cama de 90,84\%. 50\% dos entrevistados elogiaram os serviços e $22 \%$ queixaram-se da qualidade dos serviços. Ele foi apontado como o principal motivo de reclamação o serviço lento (17\%). A instituição privada recebeu 2.222 pacientes, com uma média de 570 pacientes. O tempo médio de internação foi de 4,5 dias. A taxa média mensal de ocupação cama foi de 59,9\%. Na avaliação do grau de satisfação do atendimento, regular ou ruim, a satisfação obtida foi uma taxa de $60 \%$ na instituição privada.

Conclusão: Não houve resultados favoráveis para a qualidade na gestão da saúde, tanto no serviço público como no privado

Palavras-chave: gestão de saúde, qualidade dos cuidados de saúde, avaliação de saúde. 